\title{
PENGEMBANGAN PROTOTIPE PERANGKAT PEMBELAJARAN FISIKA SMK MODEL INKUIRI TERBIMBING MATERI CERMIN UNTUK MELATIHKAN KETERAMPILAN BERPIKIR KRITIS
}

\author{
Dewi Suryani' ${ }^{1)}$, Mohamad Nur' ${ }^{2}$, Wasis ${ }^{3)}$ \\ ${ }^{1)}$ Mahasiswa Program Studi Pendidikan Sains, Program Pascasarjana Universitas Negeri Surabaya \\ ${ }^{2), 3)}$ Dosen Pascasarjana Prodi Pendidikan Sains Univesrtitas Negeri Surabaya \\ E-mail:dewis137795032@gmail.com
}

\begin{abstract}
Abstrak: Penelitian pengembangan ini bertujuan untuk mengetahui kualitas (validitas, kepraktisan, dan keefektifan) perangkat pembelajaran fisika menggunakan model inkuiri terbimbing untuk melatihkan keterampilan berpikir kritis pada materi Cermin untuk siswa kelas XI SMK Negeri 2 Kota Pasuruan. Penelitian dilaksanakan dalam dua tahap, yaitu pengembangan perangkat mengikuti rancangan Dick dan Carey, dilanjutkan implementasi perangkat pembelajaran di kelas menggunakan One Group Pretest-Posttest Design. Hasil penelitian menunjukkan bahwa perangkat yang dikembangkan telah valid, praktis, dan efektif. Valid terlihat dari penilaian validator terhadap Model Pembelajaran; Buku Guru; Buku Siswa; LKS; Instrumen Penilaian Hasil Belajar Afektif, Kognitif Produk, Proses, Keterampilan Berpikir Kritis dan Psikomotor. Praktis terlihat dari persentase keterlaksanaan tahapan pembelajaran sebesar $100 \%$, dengan skor keterlaksanaan pembelajaran di kelas XI Teknik Permesinan sebesar 3,78; aktivitas yang mendukung model inkuiri terbimbing lebih dominan dalam pembelajaran dan aktivitas tidak relevan mengalami penurunan setiap pertemuan; siswa memberikan respon positif terhadap prototipe buku siswa dan proses pembelajaran menggunakan model inkuiri terbimbing yang telah dikembangkan. Efektif terlihat dari ketuntasan individual hasil belajar kognitif produk siswa kelas XI Teknik Pemesinan sebesar 100\%; ketuntasan hasil belajar afektif dan psikomotor siswa sebesar 100\%; semua siswa mengalami peningkatan keterampilan berpikir kritis, dari seluruh siswa 3\% mengalami perubahan dari teramnil meniadi sangat teramnil: $50 \%$ dari tidak teramnil meniadi teramnil: $47 \%$ dari kurang teramnil meniadi teramnil.
\end{abstract}


kurikulum perlu dilakukan karena adanya berbagai tantangan yang dihadapi, baik tantangan internal maupun tantangan eksternal (Kemendikbud, 2014: Modul Pelatihan Guru Implementasi Kurikulum 2013, 2014:4 ). Berdasarkan kurikulum tersebut di atas, adanya pembelajaran fisika di sekolah dimaksudkan sebagai sarana untuk melatih para siswa agar dapat menguasai konsep dan prinsip fisika, memiliki kecakapan ilmiah, keterampilan proses sains, kecakapan berpikir kritis serta kreatif (keterampilan berpikir abad 21).

Sekolah merupakan tempat yang tepat untuk melatihkan keterampilan berpikir kritis siswa. Namun pada kenyataannya berdasarkan hasil studi pra penelitian di SMKN 2 Pasuruan terungkap bahwa, keterampilan berpikir kritis siswa masih rendah. Rendahnya kemampuan berpikir kritis siswa di Indonesia juga dapat dilihat dari hasil penelitian TIMSS (Trends in Mathematics and Science Study). Hasil penelitian TIMSS menunjukkan bahwa rata-rata skor prestasi sains siswa Indonesia pada TIMSS tahun 2007 adalah 427 ( peringkat 35 dari 39 negara) dan pada TIMSS tahun 2011 skor sains siswa Indonesia adalah 406 yakni berada pada peringkat 39 dari 43 negara. Skor tersebut berada di bawah skor rata-rata, yaitu 500 dan hanya mencapai level low international benchmark, artinya siswa Indonesia hanya mampu mengenali sejumlah fakta dasar namun belum mampu mengkomunikasikan dan mengaitkan berbagai topik sains, apalagi menerapkan konsep-konsep kompleks dan abstrak (dalam Kemendikbud, 2013).

Dari uraian paragraf di atas diperlukan suatu bahan ajar dalam hal ini adalah buku yang dapat memfasilitasi guru dan siswa dalam kegiatan pembelajaran sehingga tujuan pembelajaran yang ingin dicapai dapat terpenuhi. Konsep-konsep materi yang akan diajarkan guru ke siswa harus dapat disampaikan guru dengan baik agar siswa menguasai konsep materi dan memiliki keterampilan berpikir abad 21 sesuai dengan yang diharapkan oleh Kurikulum 2013. Karena Buku Fisika yang tersedia belum sepenuhnya sesuai dengan harapan guru dalam melaksanakan PBM, maka peneliti berupaya untuk membuat prototipe bahan ajar Fisika SMK yang dapat melatihkan keterampilan berpikir kritis.

\section{METODE PENELITIAN}

Jenis penelitian yang digunakan adalah penelitian pra eksperimen yang diawali dengan pengembangan perangkat pembelajaran kemudian diimplementasikan pada siswa dalam proses pembelajaran.

\section{A. Subjek Penelitian}

Subjek Penelitian adalah prototipe perangkat pembelajaran model inkuiri terbimbing pada materi Cermin dengan sasaran uji coba siswa kelas XI Teknik
Pemesinan SMKN 2 Pasuruan, dengan jumlah siswa 30 orang.

\section{B. Tempat dan Waktu Penelitian}

Uji coba II dilaksanakan pada semester genap tahun ajaran 2014/2015 sebanyak tiga kali pertemuan di kelas XI Teknik Pemesinan SMKN 2 Pasuruan.

\section{Rancangan Penelitian}

Rancangan penelitian yang digunakan dalam penelitian ini adalah one group pretest and posttest design dengan struktur desain pre eksperimen yang diadopsi dari Suharsimi (2010), sebagaimana digambarkan dengan pola sebagai berikut:

$$
\mathrm{O}_{1} \times \mathrm{O}_{2}
$$

Dengan prosedur berikut:

1. Memberikan uji awal $\left(\mathrm{O}_{1}\right)$, dengan pretes untuk mengetahui penguasaan siswa terhadap keterampilan berpikir kritis sebelum pembelajaran.

2. Memberikan perlakuan (X), dengan penerapan model pembelajaran inkuiri terbimbing pada materi Cermin.

3. Memberikan uji akhir $\left(\mathrm{O}_{2}\right)$, dengan posttest untuk mengetahui penguasaan siswa terhadap keterampilan berpikir kritis setelah pembelajaran.

\section{Variabel Penelitian}

Berdasarkan rumusan masalah, maka variabel yang diamati dalam penelitian ini adalah:

1. Keterlaksanaan pembelajaran

2. Aktivitas siswa

3. Hasil belajar pengetahuan

4. Hasil belajar keterampilan berpikir kritis

5. Respon siswa

\section{E. Prosedur Penelitian}

Prosedur penelitian ini diawali dengan pengembangan perangkat pembelajaran meliputi Rancangan Pelaksanaan Pembelajaran (RPP), Buku ajar Siswa, Lembar Kegiatan Siswa (LKS), Tes Hasil Belajar (THB), Lembar Pengamatan Aktivitas Siswa dan Angket Respon Siswa. Model Pengembangan perangkat menggunakan model pengembangan Dick dan Carey (2009:3) yang dimodifikasi dengan Nieveen (2007). Proses pengembangan diawali dengan menentukan tujuan dan diakhiri dengan evaluasi. Tahap selanjutnya adalah mengimplementasikan perangkat pada siswa di kelas dengan jumlah sampel terbatas.

\section{F. Instrumen Penelitian}

Instrumen yang dikembangkan dan digunakan dalam penelitian ini adalah:
1. Instrumen Validasi
Prototipe Perangkat

Pembelajaran 
Lembar validasi perangkat pembelajaran digunakan sebagai acuan menilai validitas perangkat yang dikembangkan. Validasi perangkat pembelajaran meliputi Validasi Prototipe Buku Guru dan Buku Siswa, Lembar Kerja Siswa (LKS), dan Lembar Penilaian (LP). Validasi perangkat dilakukan oleh dua pakar yang kompeten di bidang pembuatan perangkat pembelajaran.

2. Instrumen Kepraktisan Prototipe Perangkat Pembelajaran

a) Lembar Pengamatan keterlaksanaan RPP

Instrumen ini digunakan untuk menilai keterlaksanan RPP pada materi Cermin yang berorientasi model pembelajaran inkuiri terbimbing yang telah dikembangkan peneliti. Keterlaksanaan RPP berisi langkah-langkah yang harus dilakukan guru dalam proses pembelajaran. Penyajian keterlaksanaan dalam bentuk terlaksana dan tidak terlaksana dengan skor penilaian 1 sampai 4.

b) Lembar Keterbacaan Prototipe Buku Siswa dan LKS oleh siswa.

c) Lembar catatan Kendala dalam pembelajaran

3. Instrumen Keefektifan Prototipe Perangkat Pembelajaran.

a) Instrumen Keterampilan Berpikir Kritis data. Pengumpulan data dalam penelitian ini menggunakan teknik berikut:

1. Dokumentasi dan Validasi

2. Observasi

3. Pemberian Angket

4. Pemberian Tes

\section{H. Tehnik Analisa Data}

Tehnik analisis data dalam penelitian ini adalah:

1. Analisis validasi Perangkat Pembelajaran

Hasil penilaian terhadap perangkat pembelajaran berupa Buku Guru terintegrasi RPP, Buku Siswa, LKS, dan LP (Tes) dianalisis secara deskriptif kualitatif yaitu dengan merata-rata skor masing-masing komponen. Hasil skor rata-rata dideskripsikan sebagai berikut:

Tabel 1.Rentang Skor validasi dan Keterangan

\begin{tabular}{|l|l|l|}
\hline $\begin{array}{l}\text { Rentang } \\
\text { skor } \\
\text { validasi }\end{array}$ & Kesimpulan & Keterangan \\
\hline $1.0-1.5$ & Tidak valid & $\begin{array}{l}\text { Belum dapat digunakan, masih } \\
\text { memerlukan konsultasi }\end{array}$ \\
\hline $1.6-2.5$ & $\begin{array}{l}\text { Kurang } \\
\text { valid }\end{array}$ & $\begin{array}{l}\text { Dapat digunakan dengan } \\
\text { banyak revisi }\end{array}$ \\
\hline $2.6-3.5$ & Valid & $\begin{array}{l}\text { Dapat digunakan dengan } \\
\text { sedikit revisi }\end{array}$ \\
\hline $3.6-4.0$ & Sangat valid & Dapat digunakan tanpa revisi \\
\hline \multicolumn{2}{|c}{ (Ratumanan \& Laurens, 2011) } \\
\hline
\end{tabular}




$$
\mathrm{P}=\frac{\Sigma A}{\Sigma N} \times 100 \%
$$

Keterangan:

P : Persentase aktivitas siswa

$\sum$ A: Jumlah frekuensi tiap aktivitas yang muncul

$\sum \mathrm{N}$ : Jumlah frekuensi seluruh aktivitas siswa selama pembelajaran (Borich, 1994)

\section{Analisis Respon Siswa}

Angket respon siswa diberikan pada akhir pembelajaran keseluruhan, data respon siswa dianalisis secara deskriptif kuantitatif sehingga diketahui besarnya respon positif atau negative dari siswa selama mengikuti pembelajaran dengan model pemaknaan.Analisis data cangket respon siswa menggunakan skala Guttman. Siswa menjawab Ya bernilai (1) dan siswa menjawab Tidak bernilai (0). Kemudian dianalisis berdasarkan kelompok responden yang menjawab "Ya" dan kelompok responden yang menjawab "Tidak". Secara matematis dapat ditulis sebagai berikut:

$$
P=\frac{\Sigma R}{\Sigma N} \times 100 \%
$$

Keterangan:

$\mathrm{P}$ : Persentase respon siswa

$\sum \mathrm{K}$ : Jumlah skor respon siswa

$\sum \mathrm{N}$ : Jumlah keseluruhan skor respon siswa

Pendidikan Sains Pascasarjana Universitas Negeri Surabaya ISSN : 2089-1776

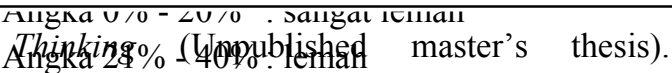
AMbłdle Forst Foohnicakuphiversity, Turkey.

Aljaafreh, LTimonlo/o

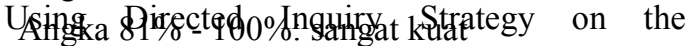
Development of Critical Thinkinguwkillsoanof 5. AnatishiqrementingarPysics of the Tenth Grade

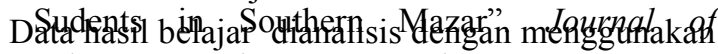

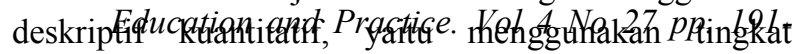

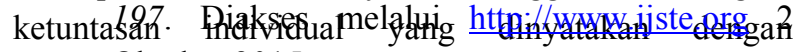
presentasetoberzantase ketuntasan dikonversi untuk

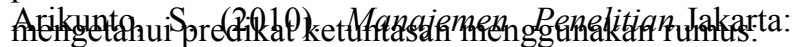
Rineka Cipta.

Borich, G. (1994). Opsewiotionor skidt g forpeeffective

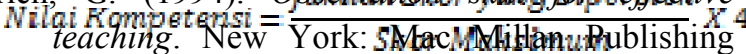
Company.

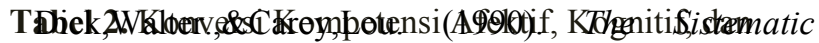
Psikomoyesign of Instruction. New Jersey: A Merill

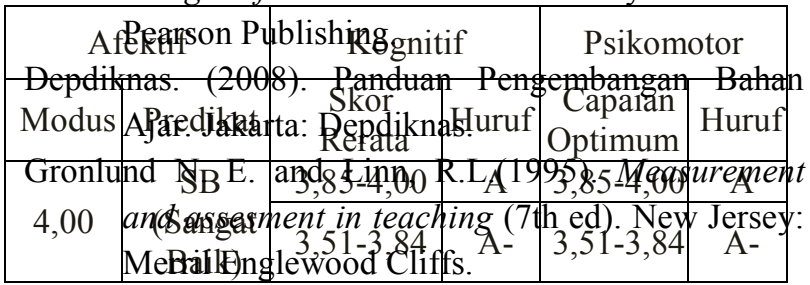

Hake.(2002). Analyzing

change/gain scores.(Online).Tersedia

http://www.

Lanjut Tabel
\begin{tabular}{|c|c|c|c|c|c|}
\hline 3,00 & B (Baik) & $3,18-3,50$ & B + & $3,18-3,50$ & B + \\
\cline { 3 - 6 } & & $2,85-3,17$ & B & $2,85-3,17$ & B \\
\cline { 3 - 6 } & & $2,51-2,84$ & B- & $2,51-2,84$ & B- \\
\hline 2,00 & $\begin{array}{c}\text { C } \\
\text { (Cukup) }\end{array}$ & $2,18-2,50$ & $\mathrm{C}+$ & $2,18-2,50$ & $\mathrm{C}+$ \\
\cline { 3 - 6 } & & $1,85-2,17$ & $\mathrm{C}$ & $1,85-2,17$ & $\mathrm{C}$ \\
\hline & $\begin{array}{c}\text { K } \\
\text { (Kurang) }\end{array}$ & $1,51-1,84$ & $\mathrm{C}-$ & $1,51-1,84$ & $\mathrm{C}-$ \\
\hline & $1,00-1,17$ & $\mathrm{D}+$ & $1,18-1,50$ & $\mathrm{D}+$ \\
\hline
\end{tabular}

(Adaptasi dari Permendikbud No.104 tahun 2014)

a. Keterampilan Berpikir Kritis

Data hasil pretest dan posttest keterampilan berpikir kritis siswa dilakukan analisis:

(1) Pemberian skor berdasarkan skala berpikir kritis, yaitu: tidak terampil, kurang terampil, terampil dan sangat terampil seperti criteria berikut:
$11.00-1.50$ :
Tidak Terampil
$21.51-2.50$ :
$32.51-3.50$ :
Kurang Terampil
$4 \quad 3.51-4.00$ :
Terampil
Diadopsi dari Rasmawan (2013)

(2) N-Gain. N-Gain menunjukkan perbedaan pengetahuan siswa sebelum dan setelah perlakuan.

$$
\langle g\rangle=\frac{\text { Spost }- \text { Spre }}{S \max -\text { Spre }}
$$

Keterangan:

$\langle g\rangle=$ Nilai gain, Sposi Vol. 6, No. 1, Nov 2016

Spre $=$ Nilai pre-test, $\operatorname{Smax}=$ Nual maksimal

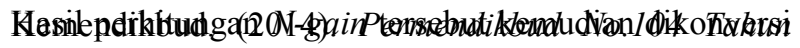

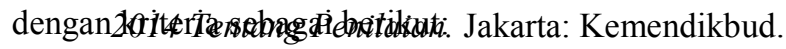

Nieveen, N dan Plomp,Tjeerd. (2007). Formative

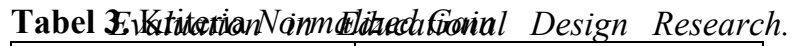

Skor Anseade: NetherlaKritarjiatenernalizedrriculum Development Gain Nuir, M-Gajpo8a). Telori-teori Belajar Kognitif $0.30 \leq$ Sürabain $\leq$ Unesa Unedane

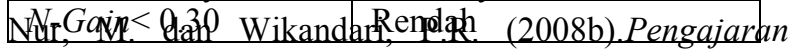
Berpusat Kepada Siswa ddn Hakertdekdtan Konstruktivitas dalam Pengajaran. Surabaya: (3) Perhithngan Propersi Ketuntasan Indikator Sains dan

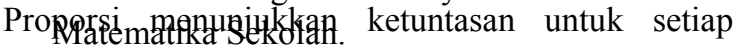
Nur, indkatordketerampilan bernikjis kritis yang diujikan setedałtabdilaketkan penpelaiarppess. dengan model

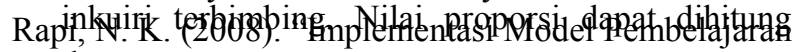
dengan persampapapin dalam Pembelajaran Fisika

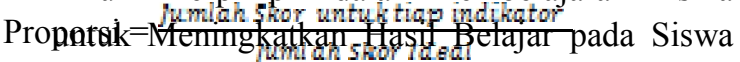
Indikelas dX Xikatakan tuntas jika nila1 proporsisi Juknal Pendidikan dan Pengajaran UNDIKSHA No.1 san yang ditetapkan oleh sekolah adalan $67^{2} .2008$.

Rasmawan, R. (2013). Memberdayakan Keterampilan

b. HasiBerpikir Aritis Siswa SMA Melalui Model Domain atektrfaran Berbasis inkuiri Pada Materi Laju Reaksi. Unesa: Tesis tidak diterbitkan. 
ditinjau dari nilai $\mathrm{N}$-gain hasil belajar kognitif produk siswa tersebut mengalami peningkatan dari sebelumnya dengan rata-rata peningkatannya 0.66 berada pada kategori sedang. Peningkatan nilai N-gain menunjukkan bahwa ketuntasan hasil belajar kognitif produk siswa setelah pembelajaran dengan model inkuiri terbimbing menunjukkan bahwa soal THB kognitif produk dengan tujuan pembelajaran yang telah dirumuskan mempunyai efek pembelajaran yang baik terhadap hasil belajar. Ketuntasan hasil belajar siswa yang mencapai $100 \%$ ini disebabkan beberapa hal, yaitu: (1) ketersediaan perangkat pembelajaran (Prototipe Buku Guru dan Buku Siswa, LKS dan Lembar Penilaian) yang berkategori baik dan reliabel; (2) RPP yang disusun guru sebelum melaksanakan kegiatan pembelajaran terencana secara rinci dan sistematis sehingga pembelajaran berjalan dengan baik; (3) keterlibatan siswa dalam pembelajaran. Menurut Piaget (dalam Slavin, 2006: 4) keterlibatan siswa secara aktif dalam pembelajaran memudahkan mereka mengasimilasi dan mengakomodasi informasi baru sehingga siswa mudah memahami fakta yang ada dalam pengalaman tersebut.

\section{Hasil Belajar Afektif}

Hasil belajar afektif siswa diperoleh dari pengamat sikap siswa selama pembelajaran yang meliputi sikap

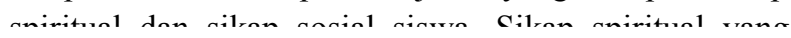
Pendidikan Sains Pascasarjana Universitas Negeri Surabaya ISSN : 2089-1776

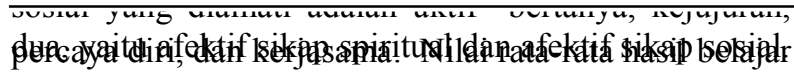

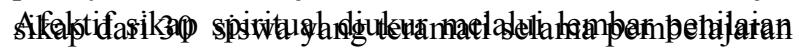

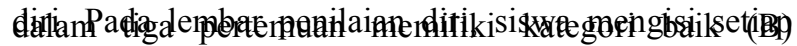

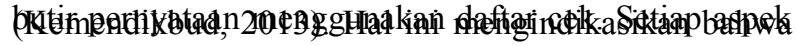

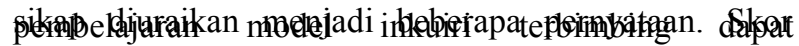

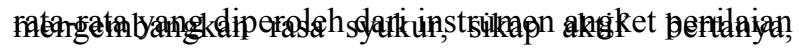

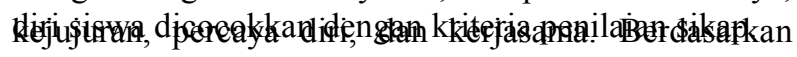

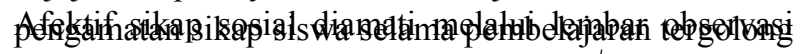

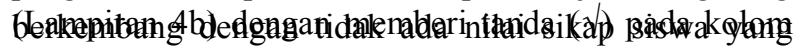

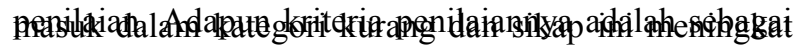
beirithkt. dengan makin seringnya pertemuan dalam proses pembelajaran. Ini sesuai dengan Krathwohl et Tabel (49Benilaian Pernyataan

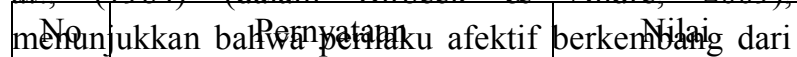
pengalansatalu dan pembiasaan dalam 4 proses \begin{tabular}{|l|l|}
\hline penabelasering gang tepat. & 3 \\
\hline
\end{tabular}

\begin{tabular}{|c|l|l|}
\hline 3 & Kadang-kadang & 2 \\
\hline \multirow{2}{*}{ K. Respon Sidakpernah } & 1 \\
\cline { 2 - 3 }
\end{tabular}

Berdasarkan hasil analisis dapat diketahui bahwa

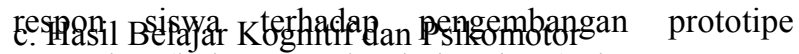

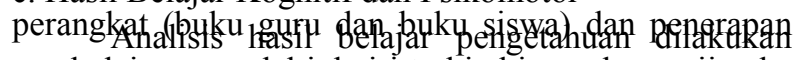

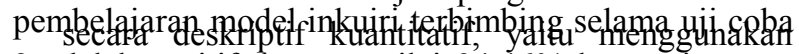

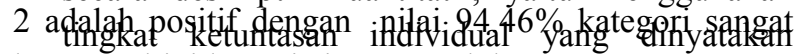

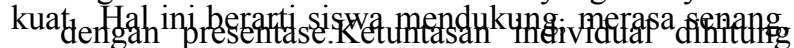

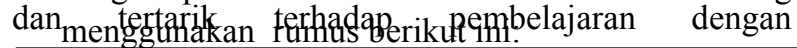

menggunakan prototype perangkat pembelajaran model inkuiri terbimbing untuk melatihkan keterampilan berpikir kritis. Ini sesuai dengan Nur (2008a), menyatakan ketertarikan dan keberminatan siswa terhadap pelajaran dan metode pembelajaran dapat meningkatkan motivasi siswa untuk belajar. Respon siswa yang positif terhadap pembelajaran model inkuiri terbimbing tidak terlepas dari perangkat pembelajaran (Prototipe Buku Guru dan Buku Siswa, LKS dan Lembar Penilaian) yang telah valid dan reliabel menurut penilaian validator dan disusun berdasarkan referensi yang mutakhir dan sesuai kebutuhan siswa (Nieveen, 2007) walaupun siswa merasakan adanya hal-hal baru dalam kegiatan pembelajaran.

\section{KESIMPULAN}

\section{A. Simpulan}

Berdasarkan hasil analisis, diskusi, dan pembahasan, maka disimpulkan bahwa prototipe perangkat pembelajaran fisika model inkuiri terbimbing pada materi cermin yang terdiri dari buku guru,buku siswa, LKS dan LP telah valid, praktis dan efektif untuk melatihkan keterampilan berpikir kritis.

\section{B. Saran}

Beberapa saran dapat dikemukakan oleh peneliti berdasarkan penelitian yang telah dilakukan, yaitu:

(1) memberikan lebih banyak perhatian dan himhingan siswa untuk melatihkan ket Vol. 6, No. 1, Nov 2016 proses sains sehagai salah satu_esemen kererampuan berpikir kritis, sehingga sisAMakikspirterdis\$stengan keterampilan-keterampilan Leppessesenganatapm Afektian keterampilan berpikir kritis Sosial Siswa kehidupan sehari-hari; (2) Angket Respon Siswa sebaiknya dibagikan pembelabih dahulu $_{\text {. }}$ sebelum pembelaiaran dimulai pagas siswa lebih mudah

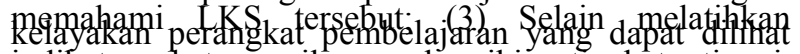
indikator keterampilan har berpikif a tingkat tinggi,

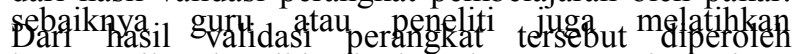
keteraykilap berroikir tingkat dasar agar siswa juga

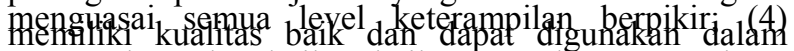
Megnaperbanyak lajatathan-latihan soal yang dapat mengaktifkan proses berpikir siswa dibandingkan dengan solerlal yanang menekankan pada perhitungan-

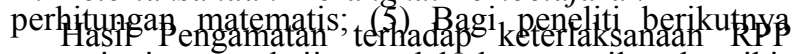
sang in inin mengkaji masalah keterampilan berpikir kritis dapat menggunakan iperangkat dalam penelitian ini sebagai bahan pembanding atau perangkat yang dikemhanckan

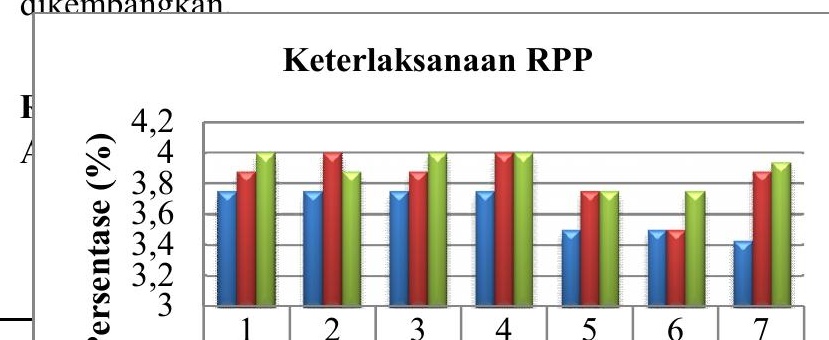


1. Hasil Belajar Keterampilan Berpikir Kritis

2. Hasil Belajar Afektif

3. Hasil Belajar Kognitif dan Psikomotor

\section{F. Hasil Pengamatan Aktivitas Siswa}

Selama proses pembelajaran dengan menggunakan model pembelajaran inkuiri terbimbing pada materi cermin yang diamati oleh dua pengamat secara ringkas dapat dilihat pada Gambar 6.

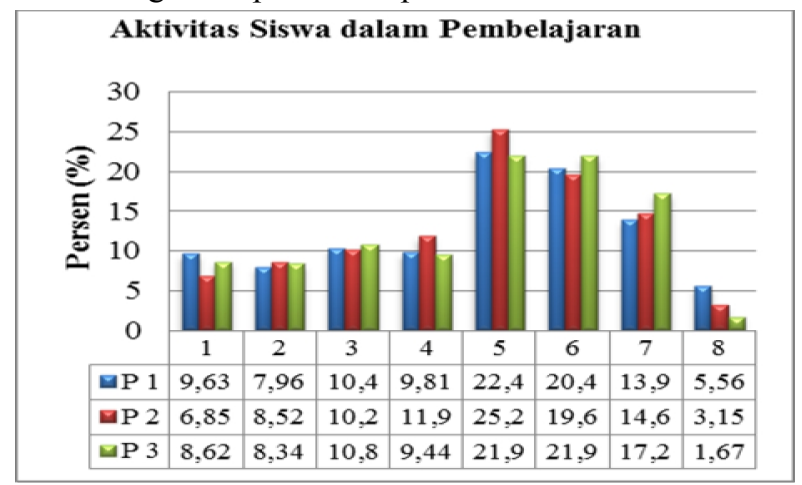

Gambar 6. Pengamatan Aktivitas Siswa Ujicoba 2

Keterangan:

1. Memperhatikan penjelasan guru

2. Bertanya kepada guru untuk minta bimbingan

3. Merumuskan masalah

4. Merumuskan hipotesis dan menentukan variabel percobaan

5. Merancang dan melakukan percobaan

6. Menganalisis data hasil percobaan

Pendidikan Sains Pascasarjana Universitas Negeri Surabaya ISSN : 2089-1776

$\gamma_{\text {. }}$ Yerılaku tıak relevan, yang melıputı:

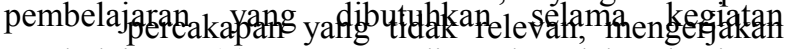

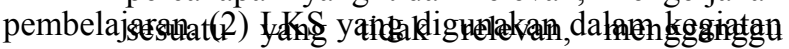

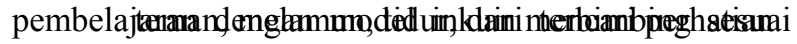
untuk melatihkan keterampilan proses sains dan Gerkikspokertisw wiswa. (3) Penguasaan guru terhadap

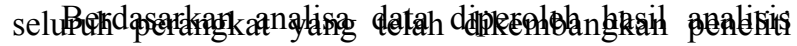

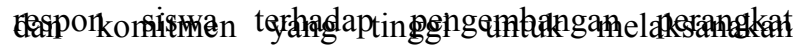

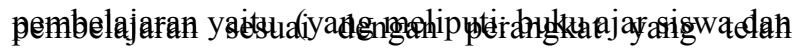

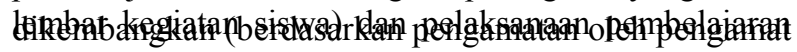

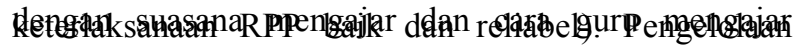

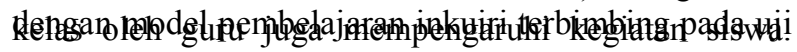
caha 2y didalatkann hasidh

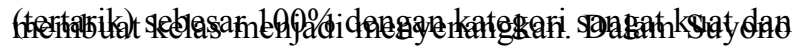

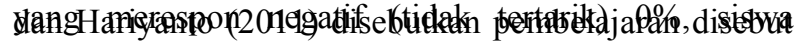

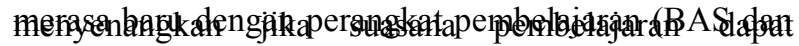

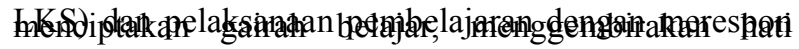

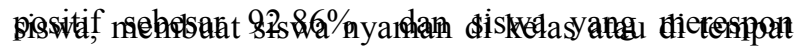
begaftif 7.y4ng. lain, sehingga siswa memusatkan

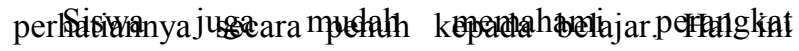

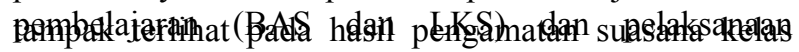

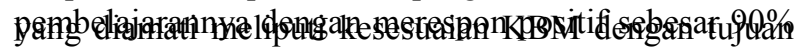

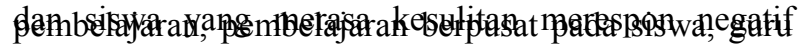

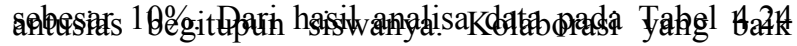

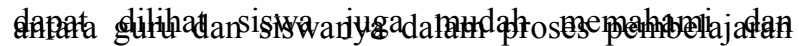

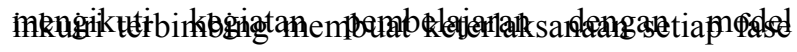

pembelajaran inkuiri terbimbing dengan merespon positif sebesar $91.43 \%$ dengan kategori sangat kuat dan yang merespon negatif hanya $8.57 \%$ dengan kategori sangat lemah. Siswa juga merespon positif dengan menyatakan tertarik apabila materi cermin diajarkan dengan model pembelajaran inkuiri terbimbing dan tertarik jika topik selanjutnya juga diajarkan dengan menggunakan model ini. Hal ini dapat dilihat dari besar respon positif sebesar $94.46 \%$ kategori sangat kuat dan yang tidak tertarik hanya $5.54 \%$ dengan kategori sangat lemah. (Riduwan, 2010).

\section{H. Keterlaksananaan Rencana Pelaksanaan}

\section{Pembelajaran}

Keterlaksanaan penggunaan perangkat pembelajaran diamati oleh dua orang pengamat.Pengamatan dilakukan selama 3 kali pertemuan yang merupakan implementasi dari RPP cermin datar, cermin cekung, dan cermin cembung. Semua tahap-tahap kegiatan yang ada di dalam RPP pada uji coba II terlaksana dan skor keterlaksanaannya pada pertemuan 1 rata-rata 3.63 , pertemuan 2 rata rata skor 3.84 dan pertemuan 3 rata-rata 3.90, semua dengan kategori Sangat baik (Ratumanan dan Laurens, 2011). Instrumen keterlaksanaan RPP mempunyai rata-rata reliabilitas $90.75 \%, 96 \%$ dan $97.5 \%$ semua berkategori baik (Borich, 1994).

Kualitas keterlaksanaan RP Vol. 6, No. 1, Nov 2016 ini tinggi karena pemilihan meda pemnelajaran yang

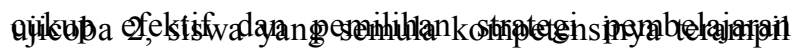
(5)

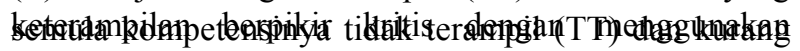

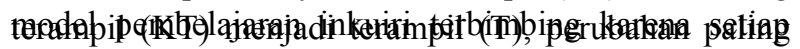

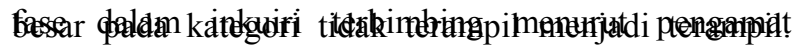

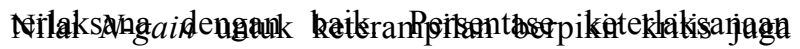

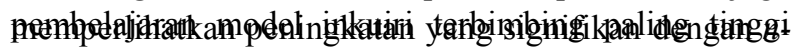

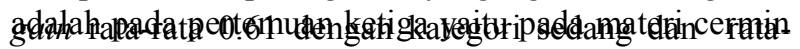

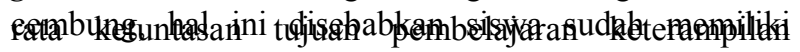

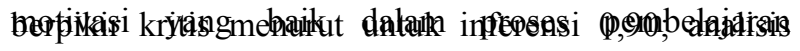

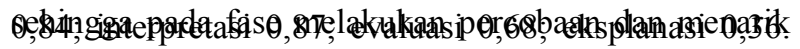

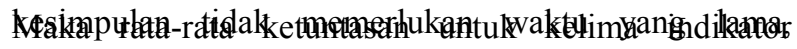
add

\section{Perubahan Keterampilan Berpikir Kritis}

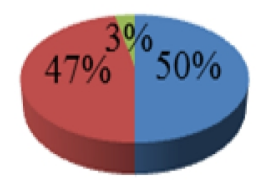

-Tidak Terampil - Terampil

-Kurang Terampil - Terampil

- Terampil - Sangat Terampil

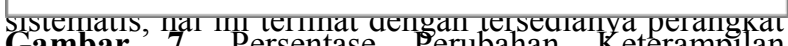
Gambar 7. Persentase Perubahan Keterampilan pembelajaran (Buku. Guru dan Buku Siswa, LKS serta Lembar Penilaian) yang memiliki kualitas baik

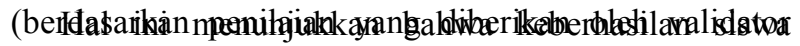

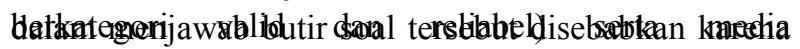

